\title{
INFLUENCE OF ARSENIC TRIOXIDE ON THE EXPRESSION OF CYCLIN A IN THE JURKAT CELL LINE
}

\author{
WPŁYW TRÓJTLENKU ARSENU NA EKSPRESJĘ CYKLINY A \\ W LINII KOMÓRKOWEJ JURKAT
}

\author{
${ }^{1}$ Department of Histology and Embryology, Nicolaus Copernicus University in Torun, \\ Collegium Medicum in Bydgoszcz \\ ${ }^{2}$ Department of Genetics, Institute of Experimental Biology, Adam Mickiewicz University Poznań \\ ${ }^{3}$ Plant Breeding and Acclimatization Institute - National Research Institute Radzików, Research Division in \\ Bydgoszcz, Department of Genetics and Breeding of Root Crops, Laboratory of Biotechnology, Bydgoszcz, Poland
}

\section{S u m m a ry}

Improper expression of cell cycle regulators is characteristic for most cancer cells. Cyclins are a group of proteins, with concentration changing in time, which control progression through each phase of the cell cycle. Maximum cyclin A expression falls inside $\mathrm{S}$ and at the beginning of $\mathrm{M}$ phase. In the $\mathrm{S}$ phase cyclin $\mathrm{A}$ is responsible for a proper run of the replication process, and together with cyclin B conditions transition into the $\mathrm{M}$ phase. Arsenic trioxide (ATO) is an efficient drug used in acute promyelocytic leukemia (AML). Numerous reports point that arsenic trioxide can be applied in therapy of other types of cancer as well. The purpose of these study was to evaluate influence of arsenic trioxide on the expression and localization of cyclin A in Jurkat cell line. Additionally, we determined the effect of ATO on morphology and ultrastructure of the Jurkat cells. In order to reach this aim we applied classic light, florescence and electron transmission microscopy. A dosedependent decrease in the percentage of viable cells was observed. Morphological and ultrastructural alterations suggest that apoptosis and autophagy are induced by ATO. Image-based cytometry showed high extent of necrotic cells after ATO treatment. A decrease in cyclin A level was observed, but without a change in protein nuclear localization.

\section{Streszczenie}

Nieprawidłowa ekspresja regulatorów cyklu komórkowego jest cechą charakterystyczną komórek nowotworowych. Cykliny stanowią grupę białek, których stężenie zmienia się w czasie, kontrolują one prawidłowy przebieg cyklu komórkowego. Cyklina A stanowi białko, którego maksimum ekspresji przypada na fazy S i G2 i jest ona odpowiedzialna za właściwy przebieg procesu replikacji w fazie $S$, a wraz z cykliną $B$ warunkuje przejście komórki do fazy M. Zastosowany w badaniu trójtlenek arsenu (ATO) stanowi skuteczny lek w terapii ostrej białaczki promielocytowej. Liczne doniesienia wskazują, że może być on także wykorzystywany w terapii innych typów nowotworów.

Celem niniejszej pracy było określenie wpływu trójtlenku arsenu na ekspresję cykliny A w linii komórkowej Jurkat. Poziom ekspresji i lokalizację cykliny A określono za pomocą klasycznego mikroskopu fluorescencyjnego. 
Ponadto zbadano wpływ trójtlenku arsenu na morfologię i ultrastrukturę komórek Jurkat przy użyciu mikroskopu świetlnego i transmisyjnego mikroskopu elektronowego. Stwiedzono zależny od zastosowanej dawki cytostatyku spadek odsetka żywych komórek. Zaobserwowane zmiany morfologiczne i ultrastruturalne sugerują indukcję apoptozy i autofagii pod wpływem trójtlenku arsenu. Badania za pomocą cytometru obrazowego wykazały wysoki odsetek komórek nekrotycznych po traktowaniu trójtlenkiem arsenu. Stwierdzono spadek ekspresji cykliny A wraz z rosnącą dawką trójtlenku arsenu, jednocześnie nie została zauważona zmiana lokalizacji cykliny z jądrowej na cytoplazmatyczną.

Key words: Jurkat cell line, arsenic trioxide, cyclin A, cell cycle, apoptosis, cell death, autophagy, mitotic catastrophe Stowa kluczowe: linia komórkowa Jurkat, trójtlenek arsenu, cyklina A, cykl komórkowy, apoptoza, śmierć komórki, autofagia, katastrofa mitotyczna

\section{INTRODUCTION}

Arsenic trioxide (ATO) has been used for medical purposes for thousands of years. Today, application of arsenic trioxide includes treatment of acute promyelocytic leukemia (APL), in which it is used as a first line drug alone and in combination-therapy [1]. Arsenic trioxide may induce apoptosis through several pathways, and the mechanism of its action differs depending on cell and tumor type. In APL cells arsenic trioxide leads to degradation of the PML-RAR $\alpha$ fusion protein and restores proper cell differentiation. In other cells ATO can induce apoptosis through the intrinsic and extrinsic pathway, arrest cells in G0/G1 and G2/M phases and trigger autophagy. Moreover, arsenic trioxide can inhibit angiogenesis [2]. In the current study we investigated the influence of ATO on the expression of one of the cell cycle regulators - cyclin A in the Jurkat cells, which are widely used as in vitro model of T-cell acute lymphoblastic leukemia (TALL). Each cell cycle is divided into two essential events: replication of DNA in $S$ phase and cell division, finally resulting in two daughter cells in $M$ phase. Progression through each phase is driven by CDKs, the activity of which depends on their partners - cyclins. The amount of CDKs do not change in time, but concentration of cyclins fluctuates, which allows activation of appropriate CDKs in accurate and ordered manner [3]. Two types of cyclin A are present in higher eukaryotes. Expression of cyclin A1 is limited to germ cells, whereas cyclin A2 (hereafter referred to as cyclin A) is present in somatic and germ cells. Cyclin A starts to accumulate from the $\mathrm{S}$ phase and is degraded in prometaphase. Cyclin A binds and activates both CDK-2 and CDK-1 and controls replication process in $\mathrm{S}$ phase, playing at the same time essential role in $\mathrm{M}$ phase entry. Moreover, cyclin A participates in chromatin condensation and nuclear envelope breakdown [4-5]. Improper expression of cyclins may cause excessive cell growth and malignant transformation; on the other hand, it may also suppress the oncogenesis [6]. Some studies suggest the involvement of cyclin A in apoptotic pathways. One of the important factors determining cyclin A function is the localization of the protein. Some studies showed link between CDK2 localization and its role in apoptosis and suggested that cyclin $\mathrm{A} / \mathrm{CDK} 2$ complexes play a twofold role as pro-survival and proapoptotic protein [7-8]. In our study we investigated how arsenic trioxide affects expression and localization of cyclin A in Jurkat cell line. Additionally, we evaluate morphological and ultrastructural changes in the treated cells.

\section{METHODS}

\section{Cell culture and treatment}

Jurkat human lymphoblastoid cell line was obtained from the Department of Dermatology and Sexually Transmitted Diseases, Nicolaus Copernicus University in Torun Ludwik Rydygier Collegium Medicum in Bydgoszcz, Poland). The cells were cultured in monolayers at $37^{\circ} \mathrm{C}$ in a humidified $\mathrm{CO} 2$ incubator (5\% CO2 in air) in RPMI 1640 (Lonza) with the addition of $10 \%$ FBS (fetal bovine serum; SigmaAldrich) and $50 \mathrm{mg} / \mathrm{ml}$ of gentamycin (SigmaAldrich). Arsenic trioxide (Trisenox, Teva Pharma B.V.) was diluted in sterile water and added to cell cultures at 1,3 , and $5 \mu \mathrm{M}$ for $24 \mathrm{~h}$. $10 \mu \mathrm{l}$ cell suspension was added to an equal volume of diluted Trypan Blue stain (Sigma-Aldrich). The number of stained cells and total number of cells was counted using Bürker counting chamber.

\section{Light microscopy}

For the morphological analysis, the Jurkat cells were fixed in $4 \%$ paraformaldehyde and then incubated with $0.1 \mathrm{M}$ glycine solution. The cells were stained with Mayer's hematoxylin, rinsed under running tap water and dehydrated in a graded series of alcohols and 
xylenes. The preparations were observed using an Eclipse E800 microscope (Nikon) with NIS-Elements image analysis system and CCD camera (DS-5Mc-U1; Nikon).

\section{Transmission electron microscopy}

Conventional electron microscopy was used to visualize Jurkat cells morphology at the ultrastructural level. The cells were fixed in 3.6\% glutaraldehyde ( $\mathrm{pH}$ 7.2, Polysciences, Warrington, PA, USA) (30 min, RT). After washing in $0.1 \mathrm{M}$ sodium cacodylate buffer (pH 7.4; Roth, Karlsruhe, Germany), the cells were postfixed in $1 \%$ buffered $\mathrm{OsO}_{4}$ (Serva, Heidelberg, Germany) for $1 \mathrm{~h}$, dehydrated in ethanol (30-90\%) and acetone (90-100\%) and embedded in Epon E812 (Roth, Karlsruhe, Germany) polymerized $24 \mathrm{~h}$ at $37^{\circ} \mathrm{C}$ and 7 days in $65^{\circ} \mathrm{C}$. Semithin sections were stained with $1 \%$ toluidine blue and used for targeting the cells. Ultrathin sections (40 nm thick) were cut with a diamond knife (Diatome, Bienne, Switzerland) by Reichert Om U3 ultramicrotome (Leica Microsystems, Vienna, Austria) on copper grids (Sigma- Aldrich; St. Louis, MO, USA) and stained with $1 \%$ uranyl acetate (Ted Pella, Inc., Redding, CA, USA) and lead citrate (Ted Pella, Inc., Redding, CA, USA). The material was examined using a transmission electron microscope JEM $100 \mathrm{CX}$ (JEOL, Tokyo, Japan) operating at $60 \mathrm{kV}$ on IMAGO EM23 film (NDT System, Warsaw, Poland).

\section{Fluorescence microscopy}

Cells were fixed with $4 \%$ paraformaldehyde $(\mathrm{pH}$ 7.4) for $15 \mathrm{~min}$, at $4^{\circ} \mathrm{C}$, washed twice with PBS and collected directly onto microscopical slides using a cytocentrifuge (Megafuge1, OR, Heraeus, Sepatech). Cells on slides were incubated in permeabilization solution (0.1\% Triton X-100 in PBS) and blocked with $1 \%$ BSA (Gibco). After permeabilization, cells were incubated with mouse monoclonal anti-cyclin A antibody (Sigma) for $60 \mathrm{~min}$ at room temperature, washed three times with PBS and incubated with Alexa Fluor 488 goat antimouse $\mathrm{IgG}$ antibody (Invitrogen) for $45 \mathrm{~min}$, at room temperature. After incubation, cells were washed with PBS and mounted in Aqua Poly/Mount (Polysciences, Inc.). Nuclear staining was performed with DAPI (Sigma). Both cyclin A and DNA staining was examined with an Eclipse E800 microscope (Nikon, Tokyo, Japan).

\section{Annexin V/propidium iodide (PI) binding assay}

Apoptosis was determined by staining cells with Tali ${ }^{\circledR}$ Apoptosis kit - Annexin V Alexa Fluor ${ }^{\circledR} 488$ and Propidium Iodide (Invitrogen) was used according to the manufacturer's instructions. In short, after the arsenic trioxide treatment, the cells were collected from 6-well plates using trypsin-EDTA solution, centrifuged at $300 \times \mathrm{g}$ for $8 \mathrm{~min}$, resuspended in $\mathrm{ABB}$ (annexin binding buffer) and incubated with Annexin V Alexa Fluor ${ }^{\circledR} 488$ at room temperature in the dark for 20 minutes. Following the centrifugation at $300 \times \mathrm{g}$ for $5 \mathrm{~min}$, the cells were again resuspended in $\mathrm{ABB}$ and incubated with propidium iodide at room temperature in the dark for 5 minutes. The cells were analyzed using a Tali ${ }^{\circledR}$ Image-Based Cytometer (Invitrogen). The data were quantified by FCS Express Research Edition software (version 4.03; De Novo Software, New Jersey, NJ, USA) and expressed as the percentage of cells in each population (viable Annexin V-/PI-; early apoptotic Annexin V+/PI-; late apoptotic Annexin V+/PI+; necrotic Annexin V-/PI+).

\section{STATISTICAL ANALYSIS}

The non-parametric Mann-Whitney $U$ test was performed to compare the differences between untreated and treated cells. The results were considered statistically significant at $\mathrm{p}<0.05$. The GraphPad Prism 5.0 (GraphPad Software) was used for statistical analyses.

\section{RESULTS}

Trypan blue staining demonstrated that treatment of Jurkat cells for $24 \mathrm{~h}$ with increasing concentrations of ATO up to $5 \mu \mathrm{M}$, decreased cell viability in a dosedependent manner. As shown in figure 1 the mean number of viable cells was $95 \%$ in the control group, $88 \%$ after $1 \mu \mathrm{M}, 79 \%$ after $3 \mu \mathrm{M}$ and $61 \%$ following 5 $\mu \mathrm{M}$ dose (Fig. 1). The changes in morphology of Jurkat cells after ATO treatment were examined under a light microscope. The control cells exhibited a typical round or kidney-shape morphology and maintained their adherence to each other (fig. 2A). Following the treatment with $1 \mu \mathrm{M}$ ATO, some cells kept proper shape but some were characterized by increased size and altered nucleus (fig. 2B). Further progression in doses caused more severe morphological changes. In cells treated with $3 \mu \mathrm{M}$ lobed nuclei were observed. The treatment with arsenic trioxide at concentration of $5 \mu \mathrm{M}$ resulted in the loss of round shape. Cells were irregular, enlarged or shrunken, some giant cells with 
large fragmented nucleus were also observed. In shrunken cells we noticed condensation of chromatin. At the highest dose arsenic trioxide caused progressive degradation as well as extensive vacuolization of the cell (fig. 2C and 2D).

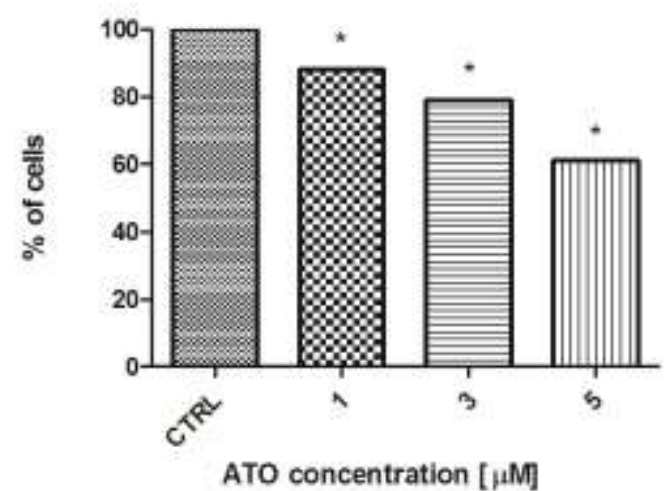

Fig. 1. The effect of arsenic trioxide (ATO) on cell survival Cells were incubated with the indicated concentrations of ATO. Asterisks denote statistical significance as compared to control cells $(\mathrm{p}<0.05)$. Results are representative of five independent experiments.

Ryc. 1. Wpływ trójtlenku arsenu na przeżycie komórek Komórki były inkubowane $\mathrm{z}$ dodatkiem trójtlenku arsenu $\mathrm{w}$ podanych stężeniach. Gwiazdki wskazują istotne statystycznie różnice $\mathrm{w}$ stosunku do komórek kontrolnych $(\mathrm{p}<0.05)$. Wyniki uzyskano na podstawie pięciu niezależnych eksperymentów.

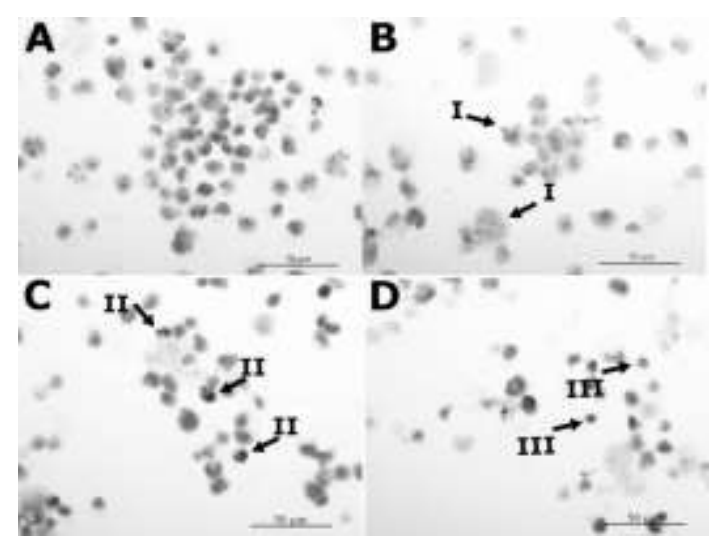

Fig. 2. The effect of ATO on the morphology of Jurkat cells A: control cells, B: cells treated with $1 \mu \mathrm{M}$ ATO, C: cells treated with $3 \mu \mathrm{M}$ ATO, D: cells treated with $5 \mu \mathrm{M}$ ATO. Bar $50 \mu \mathrm{m}$. Enlarged cells or cells irregular in shape (I), cells with lobate nucleus (II) and shrunken cells (III) were reported.

Ryc. 2. Wpływ trójtlenku arsenu na morfologię komórek Jurkat

A: komórki kontrolne, B: komórki traktowane $1 \mu \mathrm{M}$ ATO, C: komórki traktowane $3 \mu \mathrm{M}$ ATO, D: komórki traktowane $5 \mu \mathrm{M}$ ATO. Bar $50 \mu \mathrm{m}$. Widoczne powiększone komórki lub komórki o nieregularnym kształcie (I), komórki z jądrem płatowatym (II) oraz komórki obkurczone (III).
Electron microscopic studies confirmed the abovedescribed observations. The cells treated with 1, 3, 5 $\mu \mathrm{M}$ ATO showed augmented increase in ultrastructure alterations as the ATO dose increased. The control cells were regular in shape, had nucleus with distinct nucleoli and proper organelles such as the mitochondria, rough endoplasmic reticulum with visible ribosomes and Golgi apparatus (fig. 3A). The cells treated with $1 \mu \mathrm{M}$ ATO maintained their regular shape, but alterations in the nucleus were observed. Moreover, we noticed swollen mitochondria and dilation of endoplasmic reticulum (fig.3B). The incubation with arsenic trioxide at the concentration of $3 \mu \mathrm{M}$ resulted in loss of cell shape and cell membrane rupture. The nuclear volume increased slightly and condensed chromatin was visible (fig. 3C). The highest dose of ATO $(5 \mu \mathrm{M})$ caused more evident but similar changes in the majority of cells including disintegration of nucleus, and appearance of lysosomelike structures. Additionally, a considerable cytoplasmic vacuolisation was observed (fig. 3D).

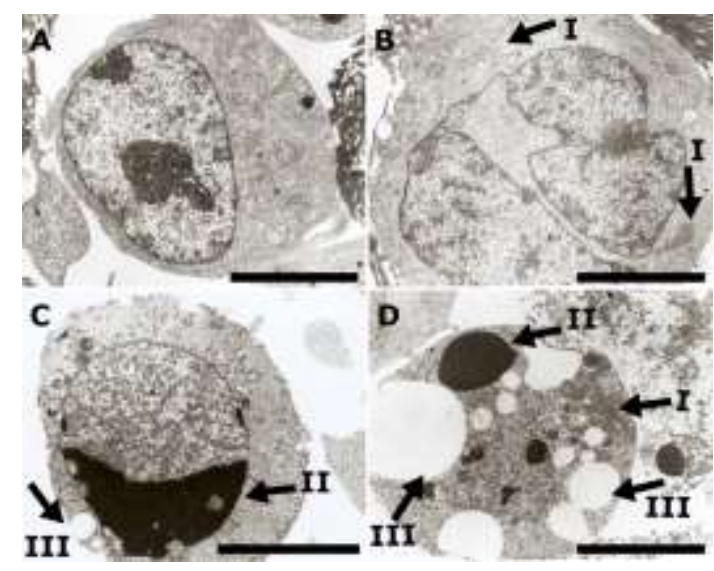

Fig. 3. The ultrastructure of Jurkat cells treated with (ATO) A: control cells, B: Cells treated with $1 \mu \mathrm{M}$ ATO, C: Cells treated with $3 \mu \mathrm{M}$ ATO, D: Cells treated with $5 \mu \mathrm{M}$ ATO. Bar $5 \mu \mathrm{m}$. Swollen mitochondria (I), chromatin condensation (II) and cytoplasm vacuolization (III) were observed.

Ryc. 3. Wplyw ATO na ultrastukturę komórek Jurkat

A: komórki kontrolne, B: komórki traktowane $1 \mu \mathrm{M}$ ATO, C: komórki traktowane $3 \mu \mathrm{M}$ ATO, D: komórki traktowane $5 \mu \mathrm{M}$ ATO. Bar $5 \mu \mathrm{m}$. Strzałkami zaznaczono obrzmiałe mitochondria (I), kondensację chromatyny (II) i wakuolizację cytoplazmy (III).

The fluorescence staining was applied to evaluate changes in cyclin A expression and localization. Arsenic trioxide strongly suppressed cyclin A expression in the Jurkat cell line. There was a statistically significant difference in the number of 
cyclin A-positive cells between the control group and ATO-treated cells. Moreover, there was no visible change in cyclin A localization. The protein was localized mainly in the nucleus in all groups; however, after ATO treatment, a small amount of cyclin A in the cytoplasm was found (Fig. 4). Next we determined the apoptotic effects of arsenic trioxide in Jurkat cells. The applied doses were highly toxic for the cells, and induced dose-dependent necrotic death. Only small extent of the cells underwent apoptosis (Fig. 5).

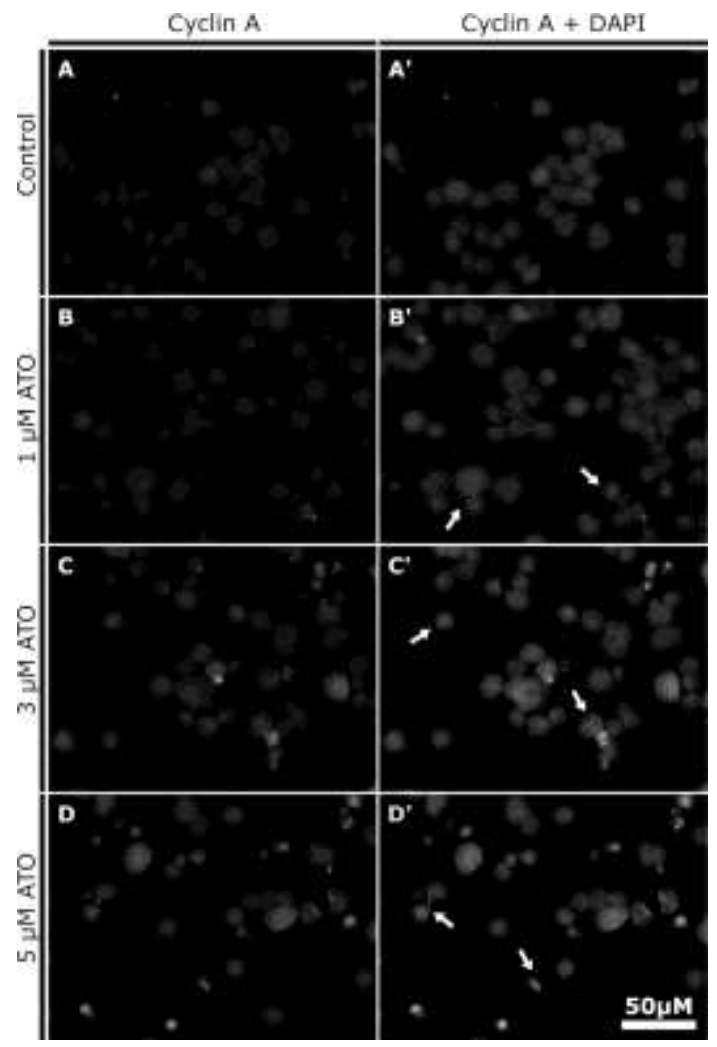

Fig. 4. Fluorescence microscopic examination of cyclin A localization in Jurkat cells treated with ATO

The cells were treated with 1,3 and $5 \mu \mathrm{M}$ ATO and immunolabeled for the presence of cyclin A (A,B,C,D). Cell nuclei were stained with DAPI (A',B',C'D'). Arrows point cells with cytoplasmic expression of cyclin A. Bar $50 \mu \mathrm{m}$.

Ryc. 4. Wptyw ATO na lokalizacje cykliny $A$ w linii komórkowej Jurkat

Komórki traktowane 1, 3 and $5 \mu \mathrm{M}$ ATO i wybarwione na obecność cykliny A (A,B,C,D). Jądra komórkowe wybarwione za pomocą DAPI $\left(\mathbf{A}^{\prime}, \mathbf{B}^{\prime}, \mathbf{C}^{\prime}, \mathbf{D}^{\prime}\right)$. Strzałki wskazują komórki z cytoplazmatyczną ekspresją cykliny A. Bar $50 \mu \mathrm{m}$.
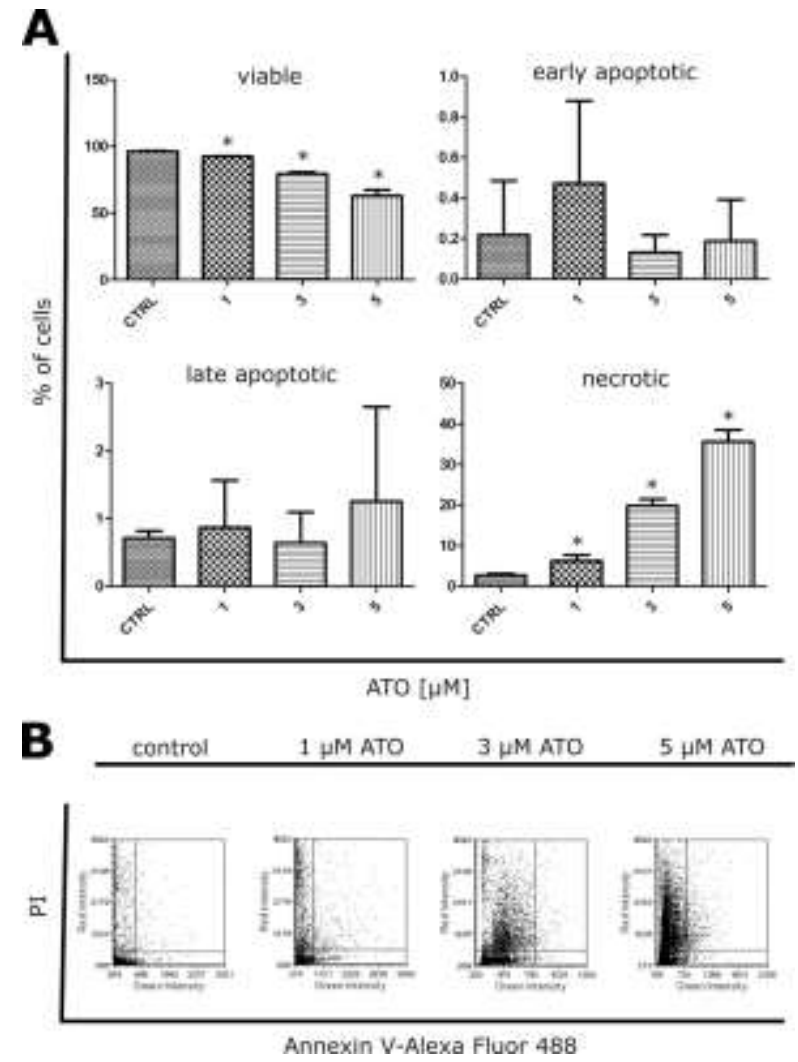

Fig. 5. Image-based cytometry analysis of apoptosis, necrosis and cell viability - annexin V/propidium iodide (PI) assay

A: The percentage of viable, early apoptotic, late apoptotic, and necrotic cells. Columns - median percentage of cells. Asterisks denote statistical significance as compared to control cells $(p<0.05)$. Results are representative of three independent experiments. B: Representative dot plots of annexin V/PI-stained cells for each of the ATO doses used.

Ryc. 5. Analiza liczby komórek żywych, apoptotycznych $i$ nekrotycznch metoda barwienia aneksyna V/jodek propidyny A: Odsetek komórek żywych, wczesnoapoptotycznych, późnoapoptotycznych oraz nekrotycznych. Kolumny - średni odsetek komórek. Gwiazdki wskazują istotne statystycznie różnice $\mathrm{w}$ stosunku do komórek kontrolnych $(\mathrm{p}<0.05)$. Wyniki uzyskano na podstawie trzech niezależnych eksperymentów. B: Reprezentatywne wykresy "dot plot" dla komórek barwionych aneksyną V i jodkiem propidyny.

\section{DISCUSSION}

T-cell acute lymphoblastic leukemia is an aggressive hematologic tumor that originates from the malignant transformation of $\mathrm{T}$ cell progenitors. T-ALL is more frequently diagnosed in children and more common in males [9]. Arsenic trioxide is a potent chemotherapeutic agent against acute promyelocytic leukemia (PML) [10-11]. Our in vitro study confirmed that ATO exerts cytotoxic effect on Jurkat cell line (immortalized line of human $\mathrm{T}$ lymphocytes). The 
observations under transmission electron microscope revealed changes in the ultrastructure which are characteristic for programmed cell death - apoptosis. We observed that Jurkat cells treated with arsenic trioxide exhibited several apoptotic hallmarks like cell shrinkage, nuclear fragmentation, membrane blebbing and chromatin condensation. Moreover, the presence of enlarged cells with one big nucleus is typical of another cell death type, called mitotic catastrophe. Mitotic catastrophe is a chain of events of delayed mitosis-linked cell death. This kind of cell death is a result of DNA damage or deranged spindle formation coupled to the debilitation of different checkpoint mechanisms that would normally arrest progression into mitosis and hence suppress catastrophic events until repair has been achieved [12]. Additionally, we observed strong vacuolization after incubation with ATO. Such a process may provide a proof that ATO can induce autophagy in Jurkat cells. It is consistent with several studies that indicate the potency of arsenic trioxide in triggering autophagy. Li et al. reported that ATO induces autophagy in Burkitt's lymphoma Raji cells [13]. It is believed that autophagy plays a dual role in cancer cells. The presence of this process as a response to chemotherapy is prosurvival and may lead to development of drug resistance, but in some cases autophagy enhance cytotoxic effect of a drug and leads to cell death [14]. However, the cytoplasmic vacuolization observed is not an explicit sign of autophagy and it is not possible to determine whether autophagy occurs without further, more detailed investigations. Nevertheless, collected data allow us to assume that arsenic trioxide can induce both apoptotic and non-apoptotic death in Jurkat cells. These results coincide with previous studies that indicated decreased cell viability and increased DNA damage in a dose-dependent manner following arsenic trioxide treatment [15]. Arsenic trioxide is an effective drug against other leukemia cell lines as well. There is some evidence for its anticancer activity in cutaneous T-cell lymphoma, malignant $\mathrm{T}$ - and $\mathrm{B}$-cell lines and HTLV-I-associated adult T-cell leukemia [16-18]. Besides, studies have shown that arsenic trioxide can be applied in non-hematological malignancies. Pettersson et al. reported that ATO in dose 1-8 $\mu \mathrm{M}$ was highly cytotoxic to small cell lung cancer lines [19]. Han et al. confirmed ATO-induced apoptosis in pancreatic cancer cells, especially in $\mathrm{CD} 24^{+} \mathrm{CD} 44^{+}$ cells [20]. In this study we investigated cyclin A expression and localization in ATO-treated Jurkat cells. Disturbed expression of key cell cycle regulators is characteristic for most cancers cells. Cyclin A plays a crucial role in G1/S and G2/M transition. Improper expression of cyclin $\mathrm{A}$ has been revealed in many cancer types, and the prognostic value of cyclin A expression varies among different studies. Ahlin et al. investigated cyclin A expression in women with breast cancer. Samples were obtained from 190 women who died from breast cancer as cases and 190 women alive at the time. The study suggests that cyclin A could predict early relapse and breast cancer death. In this report, patients with low cyclin A had longer metastases-free survival compared with patients with high cyclin A what is expected from a good proliferative marker. Moreover, survival after diagnosis was longer for patients with low cyclin A compared with high cyclin A [21]. It has been proven that ATO can deplete expression of cyclin A in different cell lines [22-23]. In the current study we observed a decrease in cyclin A expression after ATO treatment. Jun et al. reported that Jurkat cells treated with 17-alpha-estradiol showed decreased level of cell cycle regulatory proteins, cyclin $\mathrm{A}, \mathrm{E}$ and cdk4. The authors suggest that the $17 \alpha$-E2-mediated downregulation of the protein levels of cdk4, cyclin $\mathrm{A}$, and cyclin E, which led to a decrease in the level of hyper phosphorylated $\mathrm{Rb}$, might result from the accumulation of cells at the $M$ phase. In the cells arrested in G2/M apoptosis were induced through the mitochondrial cytochrome c-dependent activation of caspase cascade and subsequent PARP cleavage, which was negatively regulated by Bcl-2 [24]. It is be possible that mechanism of ATO action involves this pathway. Targeted changes in the expression profile of cell cycle-related proteins seem to be an effective strategy against Jurkat cancer cells. For example Yao et al. showed that nonylphenol, activated cell cycle inhibitors p21 and p53 and downregulated cyclin A expression in Jurkat cells [25]. The majority of cyclin A molecules locates in the nucleus. Transport of cyclin A from the nucleus to the cytoplasm has been proven, but details of the process are unclear. Cyclin A transfer from the nucleus requires binding with its CDK2 partner. In the cytoplasm cyclin A is attached to the endoplasmic reticulum by SCAPER protein ( $\mathrm{S}$ phase cyclin A-associated protein residing in the endoplasmic reticulum) [26-27]. It shall be deemed that the function of cyclin A is connected with its localization and cytoplasmic pool of this protein is involved in apoptotic pathway [7]. However, in our study the 
symptoms of extensive cyclin A shuttling between the nucleus and the cytoplasm were not observed.

In conclusion, we confirmed cytotoxic effect of arsenic trioxide on the Jurkat cell line. Our observations suggest that arsenic trioxide can induce several types of cell death. We described changes in the ultrastructure and morphology of Jurkat cells after ATO treatment. At the same time, we confirmed that arsenic trioxide could deplete expression of cyclin A, but without alterations in its localization, which is mainly nuclear. The link between apoptosis and cyclin A expression remains unclear and requires further investigation.

\section{REFERENCES}

1. Lengfelder E, Hofmann WK, Nowak D: Treatment of acute promyelocytic leukemia with arsenic trioxide: clinical results and open questions. Expert Rev Anticancer Ther, 2013; 13: 1035-1043.

2. Sánchez Y, Amrán D, Blas E et al.: Arsenic trioxide as an anti-tumour agent: mechanisms of action and strategies of sensitization. J Appl Biomed, 2010; 8: 199208.

3. Satyanarayana A, Kaldis P: Mammalian cell-cycle regulation: several Cdks, numerous cyclins and diverse compensatory mechanisms. Oncogene, 2009; 28: 29252939.

4. Gong D, JR Pomerening, JW Myers et al.: Cyclin A2 regulates nuclear-envelope breakdown and the nuclear accumulation of cyclin B1. Curr Biol, 2007; 17: 85-91.

5. Gong D, Ferrell J: The Roles of Cyclin A2, B1, and B2 in Early and Late Mitotic Events. Mol Biol Cell, 2010; 21: 3149-3161.

6. Sugrue MM, Shin DY, Lee $S$ et al.: Wild-type p53 triggers a rapid senescence program in human tumor cells lacking functional p53. Proc Natl Acad Sci USA, 1997; 94: 9648-9653.

7. Hiromura K, Pippin JW, Blonski MJ et al.: The subcellular localization of cyclin dependent kinase 2 determines the fate of mesangial cells: role in apoptosis and proliferation. Oncogene, 2002; 21: 1750-1758.

8. Goldar S, Khaniani MS, Derakhshan SM et al.: Molecular Mechanisms of Apoptosis and Roles in Cancer Development and Treatment. Asian Pac J Cancer Prev, 2015; 16: 2129-2144.

9. Van Vlierberghe P, Ferrando A: The molecular basis of T cell acute lymphoblastic leukemia. J Clin Invest, 2012; 122: 3398-3406.

10. Look AT: Arsenic and apoptosis in the treatment of acute promyelocytic leukemia. JNCI J Natl Cancer Inst, 1998; 90: 86-88.
11. Soignet L, Maslak P, Wang ZG et al.: Complete remission after treatment of acute promyelocytic leukemia with arsenic trioxide. N Engl J Med, 1998; 339: 1341-1348

12. Castedo M, Perfettini JL, Roumier T et al.: Cell death by mitotic catastrophe: a molecular definition. Oncogene, 2004; 23: 2825-2837.

13. Li CL, Wei HL, Chen J et al.: Arsenic trioxide induces autophagy and antitumor effects in Burkitt's lymphoma Raji cells. Oncol Rep, 2014; 32: 1557-1563.

14. Xu DW, Zhang GQ, Wang ZW et al.: Autophagy in tumorigenesis and cancer treatment. Asian Pac J Cancer Prev, 2015; 16: 2167-2175.

15. Yedjou C, Sutton L, Tchounwou P: Genotoxic Mechanism of arsenic trioxide in human Jurkat $\mathrm{T}$ lymphoma cells. Met Ions Biol Med, 2008; 10: 495-499.

16. Bazarbachi A, El-Sabban ME, Nasr R et al.: Arsenic trioxide and interferon-alpha synergize to induce cell cycle arrest and apoptosis in human T-cell lymphotropic virus type I-transformed cells. Blood, 1999; 93: 278-283.

17. Michel L, Dupuy A, Jean-Louis F et al.: Arsenic trioxide induces apoptosis of cutaneous $\mathrm{T}$ cell lymphoma cells: evidence for a partially caspase-independent pathway and potentiation by ascorbic acid (vitamin C). J Invest Dermatol, 2003; 121: 881-893.

18. Zhu XH, Shen YL, Jing YK et al.: Apoptosis and growth inhibition in malignant lymphocytes after treatment with arsenic trioxide at clinically achievable concentrations. J Natl Cancer Inst, 1999; 91: 772-778.

19. Pettersson HM, Pietras A, Munksgaard Persson M et al.: Arsenic trioxide is highly cytotoxic to small cell lung carcinoma cells. Mol Cancer Ther, 2009; 8: 160-170.

20. Han JB, Sang F, Chang JJ et al.: Arsenic trioxide inhibits viability of pancreatic cancer stem cells in culture and in a xenograft model via binding to SHH-Gli. Onco Targets Ther, 2013; 19: 1129-1138.

21. Ahlin C, Zhou W, Holmqvist $\mathrm{M}$ et al.: Cyclin A is a proliferative Marker with good prognostic value in nodenegative breast cancer. Cancer Epidemiol Biomarkers Prev, 2009; 18: 2501-2506.

22. Li X, Ding X, Adrian TE. Arsenic trioxide induces apoptosis in pancreatic cancer cells via changes in cell cycle, caspase activation, and GADD expression. Pancreas, 2003; 27: 174-179.

23. Lam SK, Li YY, Zheng CY et al.: Downregulation of thymidylate synthase and $\mathrm{E} 2 \mathrm{~F} 1$ by arsenic trioxide in mesothelioma. Int J Oncol, 2015; 46: 113-122.

24. Jun DY, Park HS, Kim JS et al.: 17Alpha-estradiol arrests cell cycle progression at G2/M and induces apoptotic cell death in human acute leukemia Jurkat $\mathrm{T}$ cells. Toxicol Appl Pharmacol, 2008; 231: 401-412.

25. Yao G, Ling L, Luan $J$ et al.: Nonylphenol induces apoptosis of Jurkat cells by a caspase- 8 dependent mechanism, Int Immunopharmacol, 2007; 7: 444-453. 
26. Jackman M, Kubota Y, den Elzen N et al.: Cyclin A- and cyclin E-Cdk complexes shuttle between the nucleus and the cytoplasm. Mol Bio Cell, 2002; 13: 1030-1045.

27. Tsang W, Wang L, Chen $Z$ et al.: SCAPER, a novel cyclin A-interacting protein that regulates cell cycle progression. J Cell Biol, 2007; 178: 621-633.

Address for correspondence:

Agnieszka Żuryń

Nicolaus Copernicus University

Collegium Medicum in Bydgoszcz

Department of Histology and Embryology

Karłowicza 24

Bydgoszcz 85-092, Poland

tel.: (0048)525853725

fax: (0048)525853734

e-mail: azuryn@cm.umk.pl

Adrian Krajewski - krajewski.adrian@wp.pl

Anna Klimaszewska-Wiśniewska -

ania.klimaszewska@op.pl

Alina Grzanka - agrzanka@cm.umk.pl

Magdalena Czołpińska -

magdalena.czolpinska@amu.edu.pl

Anna Litwiniec - annalitwiniec@wp.pl

Received: 23.06.2015

Accepted for publication: 10.11.2015 